\title{
Present-day stress orientations in the Great Sumatran Fault in North Sumatra
}

Article in Geotectonic Research · September 2015

DOI: $10.1127 / 1864-5658 / 2015-12$

\section{CITATION}

1

3 authors, including:

\section{David Fernández-Blanco}

Institut de Physique du Globe de Paris

14 PUBLICATIONS 47 CITATIONS

SEE PROFILE
READS

75

Melody Philippon

Université des Antilles

41 PUBLICATIONS 366 CITATIONS

SEE PROFILE

Some of the authors of this publication are also working on these related projects:

Project

ITN TOPOMOD

Project

MER Project View project 


\title{
Present-day stress orientations in the Great Sumatran Fault in North Sumatra
}

\author{
Fernández-Blanco, D. ${ }^{1}$, Philippon, M. $^{2}$ and von Hagke, C. ${ }^{3}$ \\ ${ }^{1}$ Laboratoire de Tectonique et Mécanique de la Lithosphère, Institut de Physique du Globe, 4 Rue Jussieu, 75252 Paris, Cedex 05, France \\ 2 Université des Antilles, Campus de Fouillole, 97100 Point à Pitre, UMR CNRS 5243, Géosciences Montpellier, 34095 Montpellier, France \\ ${ }^{3}$ RWTH Aachen University, Institute of Structural Geology, Tectonics and Geomechanics, Lochnerstrasse 4-20, 52056 Aachen, Germany
}

Trench-parallel strike slip faults develop at lithospheric scale during oblique high-angle subduction. A "sliver" plate forms due to slip partitioning between the subduction plane (margin-normal slip) and the strike slip fault (marginparallel slip). This process ultimately controls the location of volcanoes and earthquakes. The Great Sumatran Fault (GSF) is a showcase of this tectonic configuration located in the Sumatran section of the Sunda arc-trench system (e.g., Katili 1970; Fitch 1972) (Fig.1, upper panel). Kinematics of the large-scale structures of the Sumatra section of the Sunda trench are well understood (see McCaffrey 2009, for a review), and tensional and compressional domains have been identified at the regional scale. However, detailed understanding of the stress distribution is still lacking yet essential for evaluating the seismic hazard potential in order to mitigate the impact of the large, hazardous earthquakes associated with this system (e.g., Ishii et al. 2005; Moreno et al. 2010).

In this contribution, we study the present-day stress orientations of the Great Sumatran Fault at its northern section (NGSF). We deduced the state of (paleo)stress along structural features observed at two scales; (a) at meso-scale, analyzing ASTER GDEM data, and (b) at outcrop-scale, with field data measurements. We focus on the leading edge of northwestward propagating continental sliver deformation exposed on land, i.e. the northernmost tip of Sumatra (between $4,5^{\circ} \mathrm{N}$ and $6^{\circ} \mathrm{N}$ ), where the NGSF bifurcates into its two major branches (Jarrard 1986; McCaffrey 1991, 1992). These two fault branches form two structural highs bounding a graben basin in the onshore, continuing into the Pulau Weh Island in the east, and the Pulau Aceh Archipelago in the west (Fig. 1). Given their location at the present day deformation front, these islands provide a unique opportunity to compare the sub-recent stress field with present day stresses, contributing to the understanding of the stress field evolution during northwestwards propagation of the Sumatran forearc continental sliver.

We performed structural analysis of the GDEM using the Fault Trace module of TerraMath WinGeol ${ }^{\circledR}$ (Reif et al. 2011). This module uses a geometrical method to identify planar attributes on the basis of a minimum of three points along the intersection between geological features and topography. With this analysis we are able to detect and characterize two different transpressional fault systems in relation to the NGSF at the regional scale (Fig. 2). We determined several fault sets with faults trends between $\mathrm{N} 150$ and $\mathrm{N} 170^{\circ}$ and with dips of $50^{\circ}$ or more along the eastern branch (Fig. 2). The distribution of strike and dip of few of these fault sets suggests their development as part of conjugate faults. In the western branch we distinguished two fault sets on the basis of their dip and dip direction; faults striking between $\mathrm{N} 60$ and $\mathrm{N} 110^{\circ}$ with dip values of less than $40^{\circ}$, and faults striking between $\mathrm{N} 160^{\circ}$ and $\mathrm{N} 185^{\circ}$ with dip values higher than $60^{\circ}$ (Fig. 2)

At outcrop scale, we acquired structural data and conducted paleostress analysis in a limited number of locations given dense vegetation and restricted accessibility. When possible, we used fault slip data to derive recent paleostress histories for the area. If kinematic indicators were not available, we used data clusters derived from geometry and/or attitude of the main structures as a proxy. Data falls generally into two distinct groups. Near the western branch of the NGSF, the faults trend parallel to the main structure $\left(\mathrm{N} 205^{\circ}\right)$ and $\operatorname{dip} 55^{\circ}$, with transpressive kinematics showing displacements toward the WSW. Elsewhere, kinematic indicators are unclear, but seem to indicate clustering in relation with a roughly $\mathrm{N}-\mathrm{S}$ stress field, which associated deformation manifests as NNW-SSE strike-slip faults and E-W to ENE-WSW strike-to-oblique faults.

Based on a combination of field observations and DEM analysis, we interpret (a) the eastern branch of the GSF as a N160 trending Riedel system, with synthetic R and P systems, and (b) the western branch as a system of thrust splays and associated folds, diverging westwards from it. Along the western branch, the low-dipping faults are interpreted as thrusts and the steeply dipping ones as strike slip faults. Line-length balancing yields a minimum amount of shortening of $33 \%$ accommodated along this contractional system (Fig. 2).

These structural patterns developed in a transpressional setting along the two branches of the tip of the NGSF. Both the Riedel system and the fold and thrust belt are coherent with $\mathrm{a}_{1}$ and ${ }_{3}$ roughly trending $\mathrm{N} 010^{\circ}-\mathrm{N} 190^{\circ}$ and $\mathrm{N} 100-\mathrm{N} 280^{\circ}$, respectively. This is similar to the present day principal stress axes (e.g. McCaffrey 2009)(Fig. 3). However, the present day state of stress shows that strain is mainly accommodated along contractional structures in the Aceh Basin, located offshore, west of Sumatra along a dextral strike slip system trending parallel to the GSF (Berglar et al. 2010)(Fig. 3). Berglar et al., 2010 show that the offshore system, which propagates northwestwardly, accommodates the oblique convergence since late Miocene. Our analysis corroborates these findings. In addition we show that strain is accommodated in dissimilar manners within an overall similar stress field, resulting in apparently contrasting kinematics between the eastern and western branch of the system. We speculate that the western branch with the fold and thrust belt is a local particularity, related to early-distributed deformation of the propagating system. 


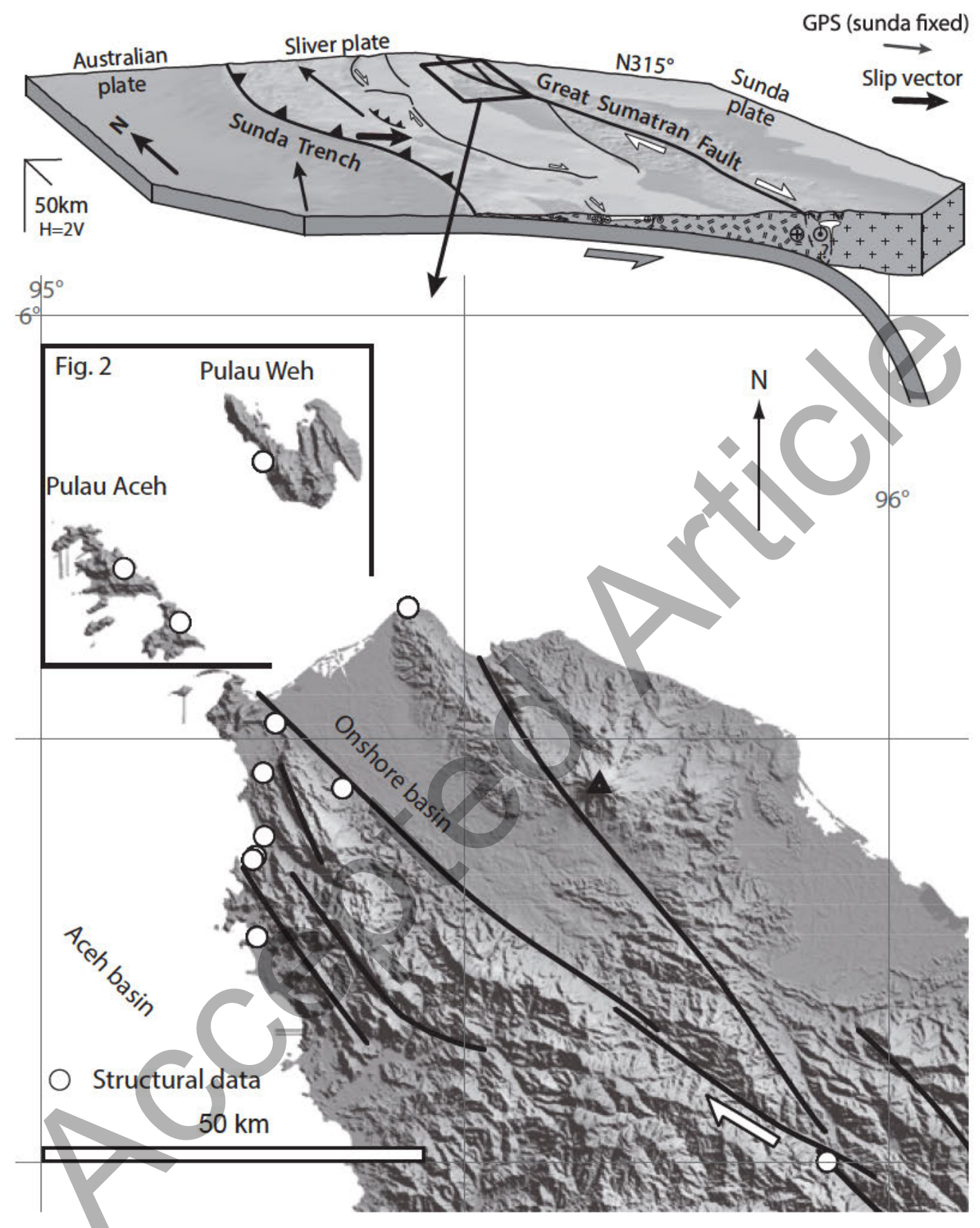

Fig. 1. 3D regional tectonic configuration in the Sumatran section of the Sunda arc-trench system (upper panel), and map-view of the GSF. White dots represent location of the data used in this contribution. 


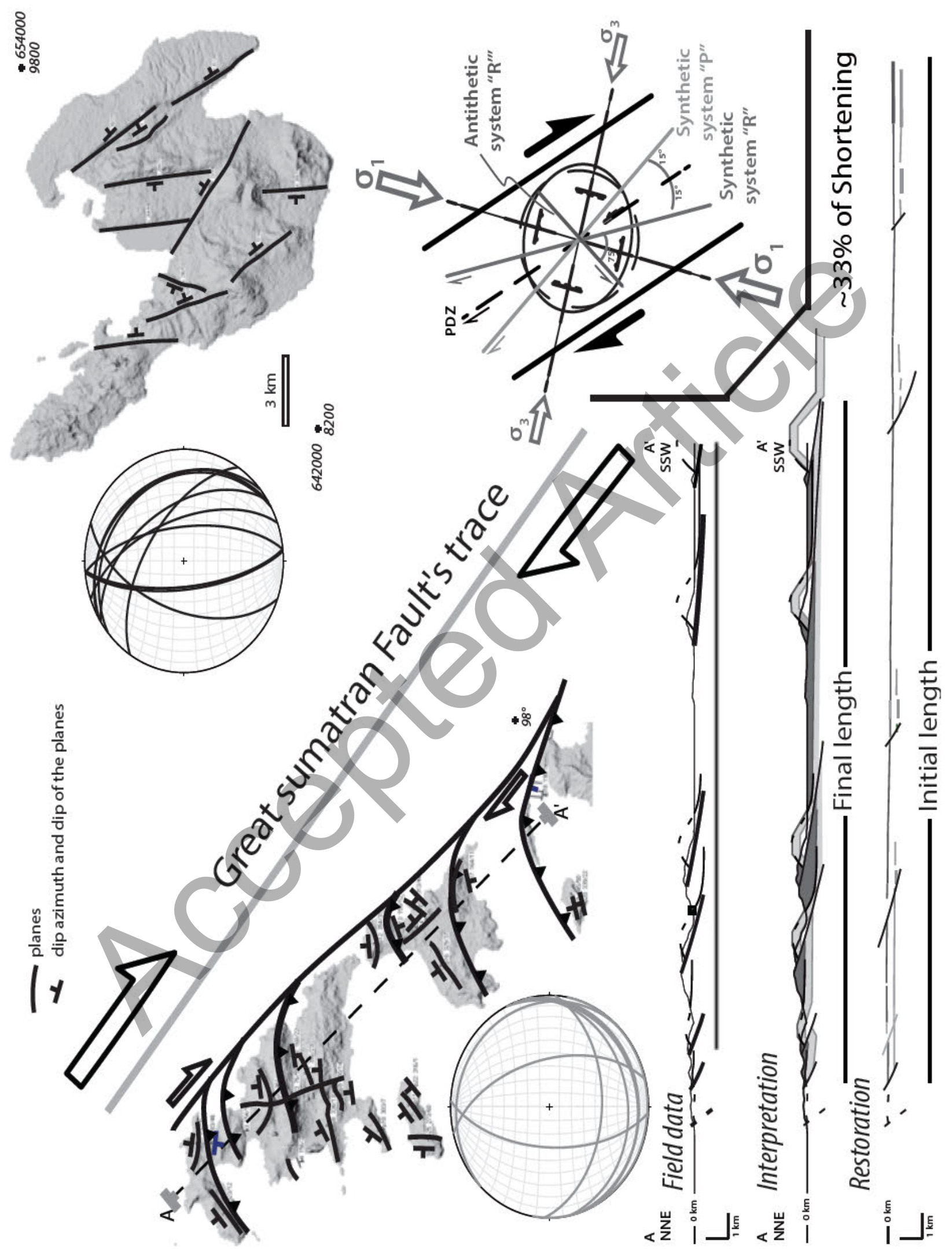




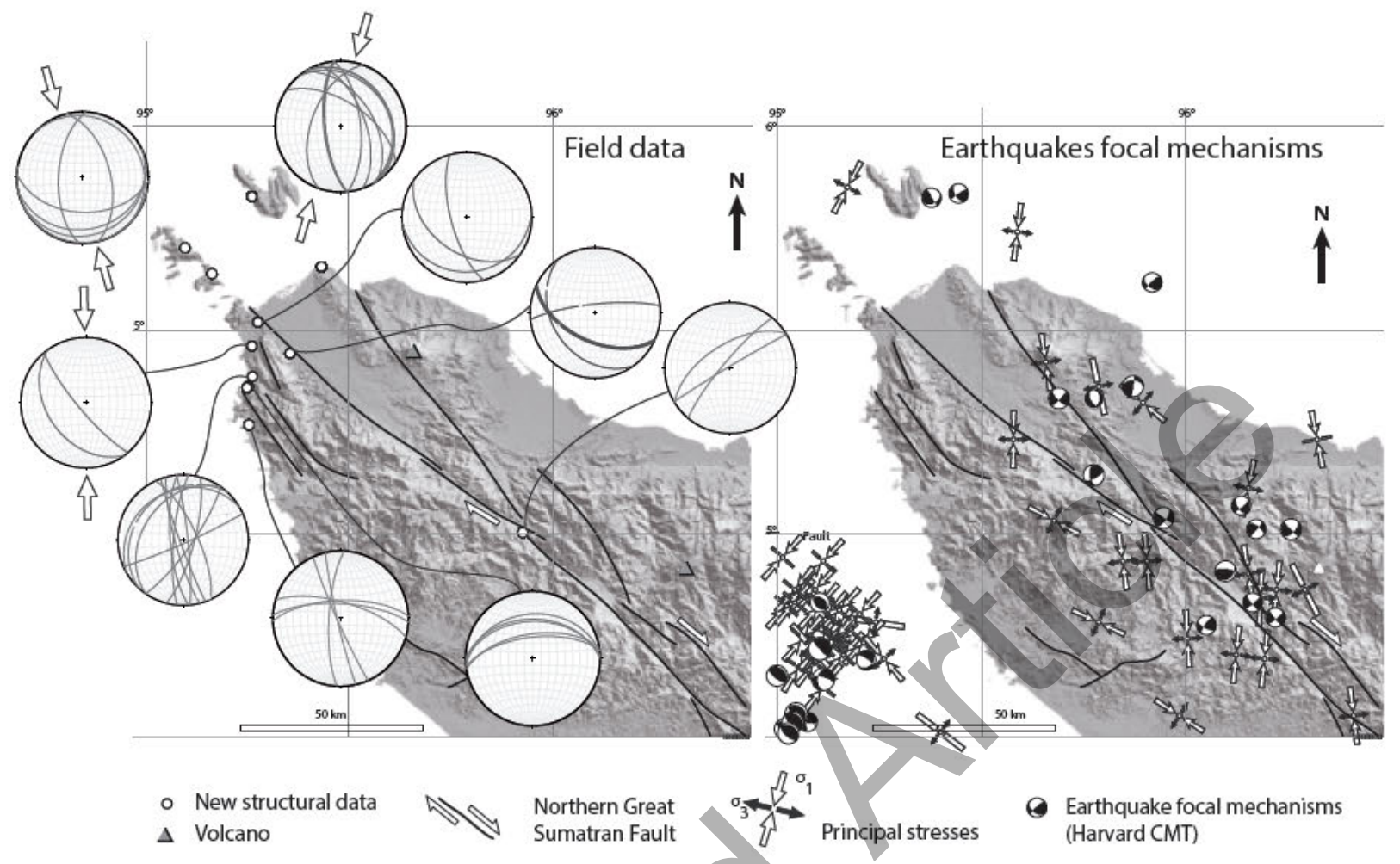

Fig. 3. Analysis of the GDEM data for the Pulau Weh island (upper-right), and the Pulau Aceh archipelago (bottom-left). Planar structures are marked in red, and used to derive the regional tectonic interpretation, shown in black. Stereplots for each island show the attitudes of planar features that interpreted as faults (in blue for Pulau Weh and in green for Pulau Aceh).

Fig. 2. Analysis of the GDEM data for the Pulau Weh island (upper-right), and the Pulau Aceh archipelago (bottom-left). Planar structures are marked in red, and used to derive the regional tectonic interpretation, shown in black. Stereplots for each island show the attitudes of planar features that interepreted as faults (in blue for Pulau Weh and in green for Pulau Aceh).

\section{References}

Berglar, K., Gaedicke, C., Franke, D., Ladage, S., Klingelhoefer, F. \& Djajadihardja, Y.S. 2010. Structural evolution and strike-slip tectonics off north-western Sumatra. - Tectonophysics 480: p. 119-132.

Reif, D., Grasemann, B., \& Faber, R. H. 2011. Quantitative structural analysis using remote sensing data: Kurdistan, northeast Iraq. AAPG bulletin 95: 941-956

Fitch, T.J. 1972. Plate convergence, transcurrent faults, and internal deformation adjacent to Southeast Asia and the western Pacific. - Journal of Geophysical Research 77: 4432-4460.

Ishii, M., Shearer, P.M., Houston, H. \& Vidale, J.E. 2005. Extent, duration and speed of the 2004 Sumatra-Andaman earthquake imaged by the Hi-Net array. - Nature 435: 933-936.

Jarrard, R.D. 1986. Terrain motion by strike-slip faulting of fore arc slivers. - Geology 14: 780-783.

Katili, J.A. 1970. Large transcurrent faults in Southeast Asia with spherical reference to Indonesia. - Geol. Rundsch. 59: 581-600.

McCaffrey, R. 1991. Slip vectors and stretching of the Sumatran fore arc. - Geology 19: 881-884.

McCaffrey, R. 1992. Oblique plate convergence, slip vectors, and fore arc deformation. - Journal of Geophysical Research 97: 8905-8915.

McCaffrey, R. 2009. The tectonic framework of the Sumatran subduction zone. - Annual Review of Earth and Planetary Sciences 37: 345-366.

Moreno, M., Rosenau, M. \& Oncken, O. 2010. 2010 Maule earthquake slip correlates with pre-seismic locking of Andean subduction zone. Nature 467: 198-202. 